\title{
The role of entrepreneurial intention in predicting vocational high school students' employability
}

\author{
Fatwa Tentama, Sabrina Yusantri
}

Faculty of Psychology, Universitas Ahmad Dahlan, Indonesia

\begin{tabular}{l}
\hline \hline Article Info \\
\hline Article history: \\
Received Mar 10, 2020 \\
Revised Jun 11, 2020 \\
Accepted Jul 14, 2020 \\
\hline
\end{tabular}

\section{Keywords:}

Employability

Entrepreneurial intention

Vocational high school

\begin{abstract}
One of the factors that contribute to the level of employability is entrepreneurial intention. This study discusses the role of entrepreneurial intentions on students' employability. The population in this study was all students of grade XII of Vocational High School Koperasi Yogyakarta, Indonesia, consisting of 141 students. The sample in this study was 86 students. The sample selection was done by randomizing using a cluster random sampling technique. Methods of data collection used in this study are scales, employability scale, and entrepreneurial intentions scale. Analysis of the data used in this study is the product-moment analysis technique. The results of data analysis showed the correlation between entrepreneurial intentions and employability where $r=0.339$ with $p=0.001(p<0.01)$, which showed a very significant positive correlation between the two variables at the research site. It means that the level of employability can be predicted based on entrepreneurial intention. The entrepreneurial intention contributed $11.5 \%$ to employability, and the remaining $88.5 \%$ can be influenced by other variables.
\end{abstract}

This is an open access article under the CC BY-SA license.

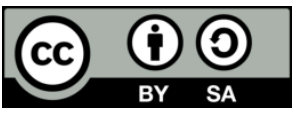

\section{Corresponding Author:}

Fatwa Tentama,

Faculty of Psychology,

Universitas Ahmad Dahlan,

Kapas Street 9, Semaki, Yogyakarta, Indonesia.

Email: fatwa.tentama@psy.uad.ac.id

\section{INTRODUCTION}

In facing the pressure of the labor market with all of its challenges, individuals need to be prepared as well as possible [1]. One of the skills that need to be prepared and developed is employability [2]. Employability is a major concern in vocational education that needs to be considered [3] because employability as a provision is required to facilitate individuals to find work in the future [4]. The level of employability can increase individuals' capacity to manage their careers [5, 6]. Developing and improving students' employability is essential [7] because it can improve work skills, communication, self-management, ability to analyze and to face difficulties [8].

Employability plays an important role in planning professional development and effective career advancement for prospective graduates. With strong employability, individuals can realize career goals and start entrepreneurship or even work [4]. Low employability has several impacts on individuals, the impact of low employability is low self-esteem, lack of effort, and willingness to enter the workforce [9]. Individuals with low employability are more constrained to enter the workforce or to get a job in accordance with their expected career [10]. In addition, the large number of unemployment today, as many have assumed, is also caused by the low employability [11]. Other impacts caused by low employability are 
inappropriate decision making, conflict, inappropriate leadership, low meta-cognitive skills, ineffective performance, low social responsibility, and pessimism [12].

Employability as a skill, knowledge, and competency are important attributes that can improve an individual's ability to get a job and subsequently give them easier access to enter the job market [13]. Employability refers to the ability of individuals to enter the workforce, adapt to the workplace, and be dynamic in the workplace $[14,15]$. Employability is the constant ability of individuals to do, to get, or to create work [16, 17]. Employability is defined as a form of skill as a part of special abilities that enable individuals to identify and realize career opportunities [18].

The concept of employability is closely related to entrepreneurial intentions [19, 20]. Some researchers find that increasing entrepreneurial intentions is believed to be a strategy that can be applied to address the problem of low employability [21]. The intention of entrepreneurship encourages individuals to engage in various tasks and challenges that require a variety of skills and knowledge [22]. Individuals with high entrepreneurial intentions tend to have entrepreneurial values, attitudes, knowledge, and skills that enable them to cope with changing needs in the labor market [23-25].

The intention of entrepreneurship is the intention to start a business and or to launch a new business [26]. This intention is further characterized as an individual's readiness to interact with entrepreneurs involved in entrepreneurial action, or new business development that consider inner guts, planning, and negotiations to face intense competition in the world of work [27]. The intention of entrepreneurship is described as a commitment that drives someone to become an entrepreneur [28]. Cognitive representation of actions to be taken by individuals to build new independent businesses [29] and a commitment to starting a new business and a tendency to act as the main force which drives new businesses [30].

The novelty of this research is the study of employability, which is directly related to intention theory, especially entrepreneurial intentions, which are still rarely done. In addition, the focus of this study, specifically on Vocational High School students in class XII. This study discusses the relationship between entrepreneurial intentions and employability in students at the Vocational High School Koperasi Yogyakarta.

\section{RESEARCH METHOD}

\subsection{Population, sample and sampling technique}

The population in this study were all students of grade XII of Vocational High School Koperasi Yogyakarta, Indonesia consisting of 141 students from three majors covering six classes. The population in this study was mainly from grade XII students because it is assumed that they had skills in accordance with their majors and had completed the job training (internship). The sample in this study was 86 students from three major classes, namely: visual communication design, accounting, and marketing. The selection of subjects was randomized using a cluster random sampling technique.

\subsection{Measuring instrument}

The data collection method in this study consists of some scales. Firstly, the employability scale was designed by the authors themselves based on the employability dimension, according to Fugate, Kinicki, and Ashforth [31], namely career identity, personal adaptability, and social and human capital. The scaling model used for this scale is the Likert scaling model. Examples of employability scale items are: "I consider learning as an important thing to support my search for a job", "I feel the practice of fieldwork can increase knowledge and ability to work", and "I share information with friends related to subject matter and practice in school". The scale of employability for collecting data is written in Indonesian.

The scale of entrepreneurial intentions was designed by the authors themselves by referring to the dimensions of entrepreneurial intentions, according to Van Gelderen, Brand, Van Praag, Bodewes, Poutsma, and Van Gils [22] namely desires, preferences, plans, and behavior expectancies. The scaling model used for this scale is also the Likert scale model. Examples of scale items of entrepreneurial intentions are: "I feel I am ready to be an entrepreneur", "I will run a business according to the expertise I have", and "I have aspirations to become an entrepreneur". The scale of entrepreneurial intentions for collecting data is written in Indonesian.

\subsection{Validity and reliability of measuring instruments}

The results of the trial analysis of 40 subjects on the scale of employability obtained the results of the reliability coefficient $(\alpha)$ of 0.886 with a range of item (corrected item-total correlation) power index that moves from 0.301 to 0.660 . Valid and reliable items used for research are 24 items. The results of the trial analysis of 40 subjects on the scale of entrepreneurial intentions obtained the results of the reliability 
coefficient $(\alpha)$ of 0.866 with a range of item power index (corrected item-total correlation) that moves from 0.304 to 0.632 . Valid and reliable items used for research are 20 items.

\subsection{Data analysis}

The method for analyzing data is parametric statistical methods. Data analysis was performed using IBM SPSS 21.0 for windows, through the product-moment technique, which is a statistical analysis technique to determine the relationship between entrepreneurial intentions and employability.

\section{RESULTS AND DISCUSSION}

\subsection{Prerequisite test}

Before doing calculations with Product moment analysis, it is necessary to do an assumption test, namely the normality test and the linearity test, as a condition for using Product moment analysis.

\subsubsection{Normality test}

The normality test is done with the aim to assess the distribution of data in groups of data or variables, whether the data distribution is normally distributed or not. The normality test is useful for determining data that has been collected in the normal distribution or taken from a normal population. Based on the results of the normality test analysis listed in Table 1, it is known that the significance value of the employability variables and entrepreneurial intentions is 0.612 and 0.413 , respectively, which have $\mathrm{p}>$ 0.05. It means that each data is normally distributed.

Table 1. Distribution normality test

\begin{tabular}{lccc}
\hline \multicolumn{1}{c}{ Variable } & Score K-SZ & Significance & Explanation \\
\hline Employability & 0.759 & 0.612 & Normal \\
Entrepreneurial intention & 0.885 & 0.413 & Normal \\
\hline
\end{tabular}

\subsubsection{Linearity test}

The linearity test aims to determine whether two variables have a linear relationship or not significantly. A linear relationship shows that changes in predictor variables will tend to be followed by changes in criterion variables by forming linear lines. Linearity test results between entrepreneurial intentions on employability shown in Table 2 obtained F linearity of 11.625 with a significance level (p) of 0.001 , which means linear or there is a line connecting the entrepreneurial intention variables to employability.

Table 2. Linearity test

\begin{tabular}{ccccc}
\hline Variable & F Linearity & Significance & Criteria & Explanation \\
\hline Entrepreneurial intention on employability & 11.625 & 0.001 & $\mathrm{P}<0.05$ & Linear \\
\hline
\end{tabular}

\subsection{Hypothesis test}

Testing the hypothesis proposed in this study done using product moment analysis. The results in Table 3 show that the magnitude of the correlation coefficient between entrepreneurial intention and employability is $r=0.339$ with $p=0.001(\mathrm{p}<0.01)$. Thus, there is a very significant positive relationship between entrepreneurial intentions and the employability of students at Vocational High School Koperasi Yogyakarta.

Table 3. Product moment correlation analysis

\begin{tabular}{cccccc}
\hline Variable & $\mathrm{r}$ & $\mathrm{R}$ Square & Significance & Criterion & Explanation \\
\hline $\begin{array}{c}\text { Entrepreneurial intention } \\
\text { on employability }\end{array}$ & 0.339 & 0.115 & 0.001 & $\mathrm{p}<0.01$ & $\begin{array}{c}\text { There is a positive and very } \\
\text { significant correlation }\end{array}$ \\
\hline
\end{tabular}

These results indicate that the proposed hypothesis is accepted so that the employability variable can be predicted based on entrepreneurial intentions. The results of this study are in line with several previous studies that found that entrepreneurial intentions play an essential role in increasing employability [32, 33]. The intention of entrepreneurship contributes $11.5 \%$ to employability, and the remaining $88.5 \%$ can 
be influenced by other variables. Factors that influence entrepreneurial intentions include soft-skill factors, problem-solving skills, internship experience, special skills, and learning achievement [34]. Some researchers add other factors that affect employability, namely: learning achievement, self-concept [35], learning motivation and social support [36], career management practices, work experience, training, and education [37]. Low employability is an important problem in the world of work, and one solution to increase employability is to instill or encourage individuals to have entrepreneurial intentions [38, 39]. The kind of intention will direct individuals to analyze market situations and adjust business innovation to market needs [40, 41]. High entrepreneurial intentions enable individuals to be seriously involved in various activities that support their business in the future [42, 43]. Individuals with entrepreneurial intentions have a greater chance of getting a job because they will try to create jobs that allow themselves to provide employment opportunities for others [44, 45].

The intention of entrepreneurship is becoming increasingly important from time to time globally [46, 47]. It works as a basic concept to meet the demand for jobs faced by both individuals and social organizations [48, 49]. The intention of entrepreneurship helps individuals to develop interpersonal skills as an important part of the process of negotiation between individuals and other parts in relation to developing new businesses [50]. High entrepreneurial intentions, when directed maximally, will create innovation, proactivity, and the courage to take risks in creating positive social impacts [51]. Individuals who have entrepreneurial intentions will focus on how they can renew or improve their knowledge and skills so that they can handle obstacles appropriately when they enter the world of entrepreneurship [52].

This research provides insight to become prospective new entrepreneurs, especially for Vocational High Schools graduates. The findings obtained indicate that individual intentions in entrepreneurship tend to play an active role in determining the involvement of individuals in building a business. Individuals with entrepreneurial intentions tend to have higher employability. The results of this study can also be useful for teachers. In addition to teaching vocational skills, teachers are also responsible for convincing students to create jobs that are in line with their potential vocational skills. Students can ask for various suggestions to direct their entrepreneurial intentions to entrepreneurial behavior according to their field, thereby hoping them not too reliant on employment, but they are able to create jobs for themselves and others.

\section{CONCLUSION}

The intention of entrepreneurship can be a good indicator of the employability of students at the Vocational High School Koperasi Yogyakarta. There is a very significant positive relationship between entrepreneurial intentions and students' employability. It means that the level of student employability can be predicted based on entrepreneurial intentions. The intention of entrepreneurship plays a role of $11.5 \%$ to employability, and the other $88.5 \%$ of the proportion might come from other factors.

\section{ACKNOWLEDGEMENTS}

The authors would like to thank the Faculty of Psychology of Universitas Ahmad Dahlan and Vocational High School Koperasi Yogyakarta for the technical assistance in this study. The authors also thank all participating students, teachers, school administrators, and other individuals for their efforts, assistance, and involvement in this research.

\section{REFERENCES}

[1] A. De Vos, S. De Hauw, and B. I. Van der Heijden, "Competency development and career success: The mediating role of employability," Journal of Vocational Behavior, vol. 79, no. 2, pp. 438-447, 2011.

[2] C. M. Van der Heijde and B. Van der Heijden, "The development and psychometric evaluation of a multidimensional measurement instrument of employability and the impact of aging," International Congress Series, vol. 1280, no. June, pp. 142-147, 2005.

[3] H. Gu, R. R. Kavanaugh, and Y. Cong, "Empirical studies of tourism education in China," Journal of Teaching in Travel \& Tourism, vol. 7, no. 1, pp. 3-24, 2007.

[4] Y. F. Wang and C. T. Tsai, "Employability of hospitality graduates: Student and industry perspectives," Journal of Hospitality \& Tourism Education, vol. 26, no. 3, pp. 125-135, 2014.

[5] N. Hess, D. M. Jepsen, and N. Dries, "Career and employer change in the age of the 'boundaryless' career," Journal of Vocational Behavior, vol. 81, no. 2, pp. 280-288, 2012.

[6] S. McArdle, L. Waters, J. P. Briscoe, and D. T. Hall, "Employability during unemployment: Adaptability, career identity, and human and social capital," Journal of Vocational Behavior, vol. 71, no. 2, pp. 247-264, 2007.

[7] S. M. Jameson, "A case study of international hospitality students' development of employability skills," CAUTHE 2008: Tourism and Hospitality Research, Training and Practice, pp. 57-59, 2008. 
[8] K. Lowden, S. Hall, D. Elliot, and J. Lewin, Employers' perceptions of the employability skills of new graduates, London: Edge Foundation, 2011.

[9] R. Benabou and J. Tirole, "Self-confidence and personal motivation," The Quarterly Journal of Economics, vol. 117, no. 3, pp. 871-915, 2002.

[10] M. Yorke and P. Knight, "Evidence-informed pedagogy and the enhancement of student employability," Teaching in Higher Education, vol. 12, no. 2, pp. 157-170, 2007.

[11] P. Ronnås and L. Shamchiyeva, Employment diagnostic analysis: Maluku, Indonesia, Geneva: International Labour Organization, 2011.

[12] D. Jackson and E. Chapman, "Non-technical skill gaps in Australian business graduates," Education + Training, vol. 54 , no. $2 / 3$, pp. $95-113,2012$.

[13] L. Brewer, Enhancing youth employability: What? Why? And How? Guide to core workskills, Geneva: International Labour Organization, 2013.

[14] M. Coetzee and H. Roythorne-Jacobs, Career counseling and guidance in the workplace: A manual for career practitioners, Cape Town: Juta and Company Ltd., 2007.

[15] E. Herr, et al, Career guidance and counseling through the lifespan, London: Prentice-Hall, 2004.

[16] D. T. Hall and D. E. Chandler, "Psychological success: When the career is a calling," Journal of Organizational Behavior: The International Journal of Industrial, Occupational and Organizational Psychology and Behavior, vol. 26, no. 2, pp. 155-176, 2005.

[17] C. M. Van der Heijde and B. I. Van Der Heijden, "A competence-based and multidimensional operationalization and measurement of employability," Human Resource Management, vol. 45, no. 3, pp. 449-476, 2006.

[18] M. Fugate and B. E. Ashforth, "Employability: The construct, its dimensions, and applications," Academy of Management Proceedings, vol. 2003, no. 1, pp. 1-6, 2003.

[19] S. Hodzic, P. Ripoll, E. Lira, and F. Zenasni, "Can intervention in emotional competences increase employability prospects of unemployed adults?" Journal of Vocational Behavior, vol. 88, no. June, pp. 28-37, 2015.

[20] F. D. Vieira and C. S. Rodrigues, "Entrepreneurial intentions of engineering students," Academic Conferences and Publishing International, pp. 712-720, 2012.

[21] E. J. Schwarz, et al, "The effects of attitudes and perceived environment conditions on students' entrepreneurial intent," Education+ Training, vol. 51, no. 4, pp. 272-291, 2009.

[22] M. Van Gelderen, et al, "Explaining entrepreneurial intentions by means of the theory of planned behaviour," Career Development International, vo. 13, no. 6, pp. 538-559, 2008.

[23] N. E. Peterman and J. Kennedy, "Enterprise education: Influencing students' perceptions of entrepreneurship," Entrepreneurship Theory and Practice, vol. 28, no. 2, pp. 129-144, 2003.

[24] H. Matlay, "The impact of entrepreneurship education on entrepreneurial outcomes," Journal of small business and enterprise development, vol. 15, no. 2, pp. 382-396, 2008.

[25] H. Oosterbeek, M. Van Praag, and A. Ijsselstein, "The impact of entrepreneurship education on entrepreneurship skills and motivation,” European Economic Review, vol. 54, no. 3, pp. 442-454, 2010.

[26] N. F. Krueger, "Entrepreneurial intentions are dead: Long live entrepreneurial intentions," International Studies in Entrepreneurship, vol. 35, pp. 13-34, 2017.

[27] M. S. Dell, "An investigation of undergraduate student self-employment intention and the impact of entrepreneurship education and previous entrepreneurial experience," Ph.D. dissertation, Sydney. University of Sydney, 2008.

[28] H. Zhao, S. E. Seibert, and G. T. Lumpkin, "The relationship of personality to entrepreneurial intentions and performance: A meta-analytic review," Journal of management, vol. 36, no. 2, pp. 381-404, 2010.

[29] S. Z. Ahmad, S. R. Xavier, and A. R. Abu Bakar, "Examining entrepreneurial intention through cognitive approach using Malaysia GEM data," Journal of Organizational Change Management, vol. 27, no. 3, pp. 449-464, 2014.

[30] C. S. Choy, J. Kuppusamy, and M. Jusoh, "Entrepreneurial careers among business graduates: match-making using theory of planned behavior," International Journal of Entrepreneurship, vol. 9, pp. 67-90, 2005.

[31] M. Fugate, A. J. Kinicki, and B. E. Ashforth, "Employability: A psycho-social construct, its dimensions, and applications," Journal of Vocational behavior, vol. 65, no. 1, pp. 14-38, 2004.

[32] W. L. Koe, J. R. Sa'ari, I. A. Majid, and K. Ismail, "Determinants of entrepreneurial intention among millennial generation," Procedia-Social and Behavioral Sciences, vol. 40, pp. 197-208, 2012.

[33] L. Pittaway and J. Cope, "Entrepreneurship education: A systematic review of the evidence," International Small Business Journal, vol. 25, no. 5, pp. 479-510, 2007.

[34] D. J. Finch, L. K. Hamilton, R. Baldwin, and M. Zehner, "An exploratory study of factors affecting undergraduate employability," Education + Training, vol. 55, no. 7, pp. 681-704, 2013.

[35] F. Tentama and M. H. Abdillah, "Student employability examined from academic achievement and self-concept," International Journal of Evaluation and Research in Education, vol. 8, no. 2, pp. 243-248, 2019.

[36] F. Tentama, et al, "Motivation to learn and social support determine employability among vocational high school students," International Journal of Evaluation and Research in Education, vol. 8, no. 2, pp. 237-242, 2019.

[37] N. Juhdi, F. Pa'Wan, N. A. Othman, and H. Moksin, "Factors influencing internal and external employability of employees," Business and Economics Journal, vol. 11, pp. 1-10, 2010.

[38] Y. Chen, et al, "IT capabilities and product innovation performance: The roles of corporate entrepreneurship and competitive intensity," Information \& Management, vol. 52, no. 6, pp. 643-657, 2015.

[39] B. Down, "Schooling, productivity and the enterprising self: Beyond market values," Critical Studies in Education, vol. 50, no. 1, pp. 51-64, 2009. 
[40] P. Serneels, K. Beegle, and A. Dillon, "Do returns to education depend on how and whom you ask?" Economics of Education Review, vol. 60, no. October, pp. 5-19, 2017.

[41] G. A. Secim, "Study on Substance Abuse Prevention," Eurasia Journal of Mathematics Science and Technology Education, vol. 13, no. 6, pp. 2485-2504, 2017.

[42] V. Saunders and K. Zuzel, "Evaluating employability skills: Employer and student perceptions," Bioscience Education, vol. 15, no. 1, pp. 1-15, 2010.

[43] UNESCO Bangkok. Asia and Pacific Regional Bureau for Education, 'Graduate Employability in Asia, Bangkok, Thailand: UNESCO Bangkok, 2012.

[44] F. K. Ulgence, "Employability of higher education institutions graduates: Exploring the influence of entrepreneurship education and employability skills development program activities in Tanzania," Dissertation, University of Siegen, Siegen, 2015.

[45] K. Komulainen, et al, "Risk-taking abilities for everyone? Finnish entrepreneurship education and the enterprising selves imagined by pupils," Gender and Education, vol. 21, no. 6, pp. 631-649, 2009.

[46] S. Mohtar and H. L. Rahim, "Social entrepreneurship, entrepreneurial leadership and organizational performance: A mediation conceptual framework," Australian Journal of Basic and Applied Sciences, vol. 8, no. 23, | pp. 184-190, 2014.

[47] H. L. Rahim and S. Mohtar, "Social entrepreneurship: A different perspective," International Academic Research Journal of Business and Technology, vol. 1. no. 1, pp. 9-15, 2015.

[48] J. G. Dees, Social ventures as learning laboratories in innovations: Technology, governance, and globalization, Boston: MIT Press Journal, 2009.

[49] M. Korhonen, K. Komulainen, and H. Räty, "Not everyone is cut out to be the entrepreneur type: How Finnish school teachers construct the meaning of entrepreneurship education and the related abilities of the pupils," Scandinavian Journal of Educational Research, vol. 56, no. 1, pp. 1-19, 2012.

[50] H. L. Rahim and N. F. M. Lajin, "Social entrepreneurship and graduate employability," International Academic Research Journal of Social Science, vol. 1, no. 1, pp. 33-40, 2015.

[51] B. Mathur-Helm and H. J. C. Van Zyl, "Exploring a conceptual model, based on the combined effects of entrepreneurial leadership, market orientation and relationship marketing orientation on South Africa's small tourism business performance," South African Journal of Business Management, vol. 38, no. 2, pp. 17-24, 2007.

[52] C. Cremin, Capitalism's new clothes: Enterprise, ethics and enjoyment in times of crisis, London: Pluto, 2011. 